\title{
EVALUATION OF NUTRITION AND HEALTH STATUS AMONG CHILDREN WITH DIABETES.
}

\author{
Mona E.M.Naga \\ Faculty Of Specific Education, \\ Home Economics Dept., Minufiy University .
}

Research Gournal Specific Fducation

Faculty of Specific Fducation

Mansoura University

ISSUE NO. 22, JUL. 2011
مجلة بحوث التربية النوعية - جامعة المنصورة

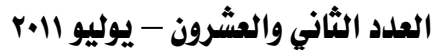




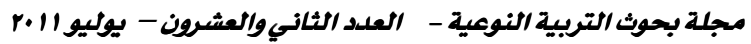

\title{
EVALUATION OF NUTRITION AND HEALTH STATUS AMONG CHILOREN WITH DIABETES.
}

\author{
By \\ Mona E.M.Naga \\ Faculty Of Specific Education, \\ Home Economics Dept., Minufiy University .
}

\section{ABSTRACT}

Nutrition obviously plays an important part in the development of overweight and obesity among children with diabetes. The present study aimed to investigate nutritional status, body measurements, food pattern, fatty acids and risk of diabetes in children, A random sample of forty diabetic children, ranged between 7-13 years, were chosen from maternity and childhood at sugar institute. Results of present study revealed that boys were shorter with lower weight compared to girls. The most frequent symptoms was polyuria and polydipsia. Mean macronutrients intake for boys and girls were higher than $100 \%$ of DRI , except for calories, calcium, phosphorus, zinc iron and vitamin $\mathrm{A}, \mathrm{B}_{1}, \mathrm{~B}_{2}, \mathrm{~B}_{12}$, intakes of girls which were less than $100 \%$. Also intake of vit $\mathrm{D} \& \mathrm{~B}_{6}$ were low for males. Mean percent of omega-6 FA (\% of RNI) was higher in girls while omega-3 FA (\% of RNI) was higher in boys. These results reflects the need for increased amount of the fiber intake, fruits, vegetables and legumes among these children and increasing milk and milk products in the diet and decreasing snack and fast foods. Increasing nutrition knowledge is also adviced. 


\title{
EVALUATION OF NUTRITION AND HEALTH STATUS AMONG CHILOREN WITH DIABETES.
}

\author{
By \\ Mona E.M.Naga \\ Faculty Of Specific Education, \\ Home Economics Dept., Minufiy University .
}

\section{Introduction}

Nutrition recommendations are developed and implemented to meet treatment goals and desired outcomes for children with type 2 diabetes. It is essential that ongoing nutrition self-management education and care be provided for individuals with diabetes American diabetes affectation (ADA). Nutrition status should be evaluated for children with type 1 Diabetes mellitus (DM) as they are growing and they are usually underweight with malnutrition probably because of diabetes itself as a debilitation disease or because of associated celiac disease (American Diabetes Association, 2000).

One of the first steps in managin g type $1 \mathrm{DM}$ is diet control. The diet treatment is based upon nutritional assessment and treatment goals. Diet recommendations should be made in view of the patient's eating habits and lifestyle. Diet management includes education about the timing, size, frequency, or composition of meals to avoid hypoglycemia or postprandial hyperglycemia. In these patients, the caloric distribution is important; a recommended distribution consists of $20 \%$ of daily calories for breakfast, $35 \%$ for lunch, $30 \%$ for dinner, and $15 \%$ for late evening snack. The minimum protein requirement for good nutrition is $0.9 \mathrm{~g} / \mathrm{kg} / \mathrm{d}$ (range $=1-1.5$ $\mathrm{g} / \mathrm{kg} / \mathrm{d}$ ), at intake should be limited to $30 \%$ or less of the total calories, and a low-cholesterol diet is recommended. Patients should consume sucrose in moderation and increase their fiber intake. In some cases, mid morning and mid afternoon snacks are important to avoid hypoglycemia. The role of diet in type 1 is to provide adequate nutrition for proper growth, supplement nutrition deficiency secondary to diabetes and to help in metabolic control of diabetes namely hyperglycemia (American Diabetes Association, 2001). The present study aimed to assess dietary nutritional status in relation to 
body measurements, and metabolic control among children with type1 diabetes

\section{SUJECTS AND METHODS}

\section{Subjects:}

A total number of 40 patients with type 1 diabetes mellitus for more than 3 years who were receiving their diabetic care at the diabetic unit in the outpatient department of sugar institute were recruited. They were divided into 2 groups: Group 1 for boys $(n=20)$ and group 2 for girls $(n=20)$. The age of children range was 7-13 years. Exclusion criteria included type 2 diabetes, presence of acute illnesses, acute diabetic complications as diabetic ketoacidosis, chronic diabetic complications. Children diagnosed with celiac disease were excluded as well as children who were under special dietary restriction other than for diabetes or receiving any form of dietary supplementations.

\section{Methods:}

\section{Des caption of subjects:}

1- Demographic data :Age, gender, degree of consanguinity, type of diabetes mellitus, number of the diabetics in the family and smoking among fathers.

2- Socioeconomic data: level of education, occupation of parents, school year, and family income.

\section{3- Biodemographic Status}

a. The most frequent symptoms encountered by the children during the course of their illnesses.

b. The cause of disease as believed by the child: Genetics, food induced, psychological state, viral induced, immunity related or unknown

c. The change of the weight as noticed by the child:

d. The history of regular exercise.

\section{4- Dietary history:}

a. The daily food consumed, using 24 hour recall method.

b. Food that they like, or dislike.

c. Food intake when children feel hungry according to( WHO, 1995). 


\section{Physical examination:}

\section{Anthropometric measurements:}

Anthropometric measurements and percentile body mass index for age were performed for all children according to the method of(Jellyfe, 1966).

\section{Biochemical analysis:}

1. Hemoglobin level was determined as the method published by to Waterman et al.,(1975).

2. -Blood sugar level was determined by home blood glucose momiter.

\section{Nutritional assesment:}

Daily dietary consumption by each child was calculated using Food composition Tables (Nutrition Institute, 1996). Total fat (g), saturated fatty acid SFA (g) monounsaturated MFA (g) and polyunsaturated PFA (g) were calculated. The adequacy of diets with regard to dietary references Intake (DRI, 2000) and Recommended Dietary allowances (RDA, 1989) was calculated. Food frequency information were Analyzed according to krauss and Mohan (1992).

\section{Statistical analysis}

Of all data were performed by using computer program, Statistical Package Social Science ( SPSS, 1998).

\section{RESULTS AND DISCUSSION}

Table (1) shows the mean age, weight, height and BMI for the studies groups. Means for age, weight and BMI were nearly equal in boys and girls patients, while the height was higher in girls than in boys significantly"

According to the BMI curves (for boys mean age was $8.5 \pm 1.83$, BMI was $22.03 \pm 15.01$, for girls, mean age was $8.7 \pm 1.91$, and BMI was 21.78 \pm 13.75 ). This significant difference could be explained by the earlier growth spurt in girls. BMI for both boys and girls are higher than their 95 percentile . These results agreed with that of Nafiu et al., (2007). 
Data in table (2) shows the socio-economic status of patients. It is noticed that all the studied children were in the primary school, boys were clustered in the $3^{\text {rd }}$ year (30\%) and girls in the fifth year (25\%). It can be seen that $40 \%$ of fathers of boys children received education to the middle level, while those of girls children were nearly equal in their educational level. For mothers education level of boys children $25 \%$ received middle or secondary education, while, $35 \%$ of those of boys received middle education. History of smoking by fathers were detected in $45 \%$ of boys and $40 \%$ of girls children. High family income ( $\geq 6000$ SR monthly) is found in $60 \%$ among boys and $50 \%$ among girls.

Table (3) shows the most frequent presenting symptoms among boys children with type 1 diabetes which were polyurea, dry mouth, dizziness, hunger pains, sweating, and less frequently blurring of vision. Among the girl children, symptoms were polyurea, hunger pains, and less frequently sweating. dizziness, blurring, mouth \& dryness . Polyurea is more in boys than girls (25\% of boys and $15 \%$ in girls ). On the other hand, other non diabetes related common symptoms was sneeze $(25 \%$ of boys and 30\% in girls). These findings agreed with Jasinskl et al .,(2003) who stated that prevalence of dryness mouth, polydpsia and polyuria and agreed with Rosenbauer et al., (2002) who reported that polyuria was the most common symptom.

Data in table (4) shows the biodemographic status.weight loss was in $60 \%$ and $50 \%$ for boys and girls respectively white exercise appear in boys as $55 \%$ and $75 \%$ of girls were no excerceis. These results agreed with Rosenbauer et al., (2002) and Jasinski et al., (2003).

Data in table (5) shows the hemoglobin level and glucose level for studied samples.

It noticed that $60 \% \& 50 \%$ of boys and girls patients respectively have moderate hemoglobin level (13-14 gm/dl). Also $75 \%$ \& $85 \%$ for boys and girls patients respectively had uncontrolled fasting blood sugar level (>130 mg/dl). $70 \%$ \& $60 \%$ of boys and girls, respectively had uncontrolled post prandial blood sugar levels $(\geq 160 \mathrm{mg} / \mathrm{dl})$ and $65 \%$ \& 55\% respectively had $>200 \mathrm{mg} / \mathrm{dl}$ random blood sugar.

Table (6) shows the type of the meal snacks, $85 \%$ of boys and $90 \%$ of girls consume snaks. Children were found to consume snacks when they felt hungry, not according to the dietary prescription by their dieticians. For 
boys snacks were $40 \%$ chips, $20 \%$ chocolate, $15 \%$ sweets or jams and $10 \%$ ice cream; for girls showed $25 \%$ sweets, $20 \%$ chips or ice cream, or jams, and $15 \%$ chocolate.

In table (7) the number of daily meals results show that $50 \%$ of boys and $45 \%$ of girls have five meals daily, $75 \%$ of boys and $65 \%$ of girls eat breakfast, $55 \%$ of boys and $60 \%$ of girls consume dairy products daily of them and $15 \%$ of boys and $25 \%$ of girls consume dairy products twice daily. Thirty $\%$ of boys and $40 \%$ of girls consume legumes, $20 \%$ of boys and $35 \%$ of girls consume bran bread, $80 \%$ of boys and $65 \%$ of girls consume white bread, $65 \%$ of boys and $55 \%$ of girls consume red meat, and $100 \%$ of boys and $95 \%$ of girls consume chicken meat. Forty $\%$ and $65 \%$ of boys and $50 \%$ and $75 \%$ of girls consume fresh vegetables and fruits respectively.

\section{Table (8): Mean \pm SD Of Macronutrients Intake Of Children .}

Data of table (8) shows the mean daily nutrients intake by diabetic children, compared to their DRI. Mean macronutrients for boys and girls were higher than $100 \%$ of DRI except for carbohydrates for both gender ( $87 \%$ boys and $95 \%$ girls) and calories (90\%) for girls only. On the other hand, macronutrients intake for boys were higher than girls except for protein-Plant and fat-Plant. These results agreed with Kylberg et al., (1985).

Mineral intake of boys was higher than $100 \%$ of DRI except for zinc (95\%) that consumed at lower than $100 \%$ of DRI. While minerals intake of girls were lower than $100 \%$ of DRI except for sodium, potassium and magnesium which consumed at higher than $100 \%$ of DRI. Mean vitamins intake of boys were higher than $100 \%$ of DRI except vitamin D and $\mathrm{B}_{6}$. While mean vitamins intake of girls were lower than $100 \%$ of DRI except vitamin $\mathrm{C}$, niacin and folates. These results agreed with that of Patton et al., (2007) who reported that mean vitamin B12 and calcium intake were less than the dietary reference intake for girl children.

Table (10) shows the value of mean daily consumption of saturated, monoenoic, polyenoic and total unsaturated fatty acids, as percent, for the different sex groups. For boys C18:0, C14:0, C16:0 and C10:0 fatty acids with the highest percentage intake among other saturated fatty acids $(21.77 \%, 20.49 \%, 21.77 \& 17.63 \%)$ respectively, which were for girls C10:0, C18:0 and C16:0 fatty acids had the highest percentage intake among other saturated fatty acids $(19.42 \%, 19.42 \%$ and $16.39 \%)$ 
respectively. In the present study $\mathrm{C} 16: 1$ fatty acid had the highest percentage intake among other monounsaturated fatty Acids $50.84 \%$ and $35.58 \%$ ) for boys and girls respectively. Also C18:2 fatty acids showed the highest percentage intake among other polyunsaturated fatty acids $(69.66 \%$ and $83.28 \%$ ) for boys and girls respectively, while C20:4 fatty acid had the lowest intake among other polyunsaturated fatty acids being Nil for gender.

Table (11) shows the mean daily intake of fatty acids fractions and their percentage of essential fat daily intake according to different sex groups. It is noticed that mean percentage of omega-6 FA (\% of RNI) was $50.26 \%$ in girls which was higher than boys $(26.58 \%)$, but percentages for boys and girls were less than $100 \%$ of RNI. While the percent of omega-3 FA\% of RNI in boys was higher than in girls. T.unsat. FA/T.sat. FA and P/S in girls were higher than boys previously. Orton et al., (2007) cullied out a comparison between omega- 3 and omega- 6 polyunsaturated fatty acid intake as assessed by a food frequency in young children at risk for developing type 1 diabetes. (Habib, 2005) recorded that prevention of diabetic ketoacidosis and reduction of its frequency should be a goal in managing children with diabetes and medical information and general awareness can contribute to this.

\section{Recommendations}

This study advise, recommended increasing the intakes of fiber, legumes, fruits and vegetables And increasing milk and milk products in diet as and decreasing snack meals. It is recommended to increase intake of fiber, legumes, fruit and vegetables and also increase intake of milk and milk production in diet . In controly,It is recommended to decrease snack meals. Increasing nutritional knowledge as well awareness and medical in for motions for parents and children in particularly care be provided for individuals with diabetes. 
Table (1): Mean \pm SD of age, anthropometric measurements for boys and girls patients with type 1 diabetes.

\begin{tabular}{|l|c|c||}
\hline \multirow{2}{*}{ Parameters } & Boys $(\mathbf{n}=\mathbf{2 0})$ & Girls(n=20) \\
\cline { 2 - 3 } & Mean \pm SD & Mean \pm SD \\
\hline \hline Age (years) & $\mathbf{8 . 5} \pm \mathbf{1 . 8 3}$ & $\mathbf{8 . 7} \pm \mathbf{1 . 9 1}$ \\
\hline Weight $($ Kg) & $\mathbf{2 7 . 1} \pm \mathbf{5 . 6 8}$ & $\mathbf{2 8 . 1} \pm \mathbf{7 . 2 2}$ \\
\hline Height $(\mathbf{c m})$ & $\mathbf{1 1 1 . 3 2} \pm \mathbf{2 0 . 6 6}$ & $\mathbf{1 1 4 . 7 4} \pm \mathbf{1 5 . 2 5} *$ \\
\hline BMI $(\mathrm{Kg} / \mathbf{m} 2)$ & $\mathbf{2 2 . 0 3} \pm \mathbf{1 5 . 0 1}$ & $\mathbf{2 1 . 7 8} \pm \mathbf{1 3 . 7 5}$ \\
\hline
\end{tabular}

$* \mathrm{P}<0.05$

Table (2): Frequency distribution of boys and girls patients according to socioeconomic status.

\begin{tabular}{||l|c|c|c|c||}
\hline \multirow{2}{*}{$\begin{array}{l}\text { Social Groups } \\
\text { Economic Factor }\end{array}$} & \multicolumn{2}{|c|}{ Boys (n=20) } & \multicolumn{2}{c|}{ Girls (n=20) } \\
\cline { 2 - 5 } School Year & No & $\%$ & No & $\%$ \\
\hline Second & & & & \\
\hline Third & 5 & 25 & 7 & 35 \\
\hline Fourth & 4 & 30 & 3 & 15 \\
\hline Fifth & 2 & 10 & 3 & 15 \\
\hline Sixth & 3 & 15 & 2 & 25 \\
\hline Levels of education of fathers & & & & \\
\hline Primary level & 7 & 35 & 6 & 30 \\
\hline Middle level & 8 & 40 & 7 & 35 \\
\hline Secondary level & 5 & 25 & 7 & 35 \\
\hline Level of education of mothers & & & & \\
\hline Illiterate & 4 & 20 & 2 & 10 \\
\hline Primary level & 2 & 10 & 2 & 10 \\
\hline Middle level & 5 & 25 & 7 & 35 \\
\hline Secondary level & 5 & 25 & 4 & 20 \\
\hline College level & 4 & 20 & 5 & 25 \\
\hline Smoking among fathers & & & & \\
\hline Yes & 9 & 45 & 8 & 40 \\
\hline No & 11 & 55 & 12 & 60 \\
\hline Family Income (SR) & & & & \\
\hline$<3000$ & 3 & 15 & 3 & 15 \\
\hline $3000-6000$ & 5 & 25 & 7 & 35 \\
\hline$>6000$ & 12 & 60 & 10 & 50 \\
\hline \hline
\end{tabular}


Table (3): The most frequent presenting symptomsamong children with type 1 diabetes .

\begin{tabular}{||l|c|c|c|c||}
\hline \hline \multirow{2}{*}{ Symptoms } & \multicolumn{2}{|c|}{ Boys(n=20) } & \multicolumn{2}{c||}{ Girls (n=20) } \\
\cline { 2 - 5 } & No & $\mathbf{\%}$ & No & \% \\
\hline \hline Dizziness & $\mathbf{2}$ & $\mathbf{1 0}$ & $\mathbf{2}$ & $\mathbf{1 0}$ \\
\hline Blurring of vision & $\mathbf{1}$ & $\mathbf{5}$ & $\mathbf{2}$ & $\mathbf{1 0}$ \\
\hline Polyurea & $\mathbf{5}$ & $\mathbf{2 5}$ & $\mathbf{3}$ & $\mathbf{1 5}$ \\
\hline Dryness of mouth & $\mathbf{3}$ & $\mathbf{1 5}$ & $\mathbf{2}$ & $\mathbf{1 0}$ \\
\hline Hunger Pains & $\mathbf{2}$ & $\mathbf{1 0}$ & $\mathbf{3}$ & $\mathbf{1 5}$ \\
\hline Sweating & $\mathbf{2}$ & $\mathbf{1 0}$ & $\mathbf{2}$ & $\mathbf{1 0}$ \\
\hline Other symptoms (Sneeze) & $\mathbf{5}$ & $\mathbf{2 5}$ & $\mathbf{6}$ & $\mathbf{3 0}$ \\
\hline
\end{tabular}

Table (4): Biodemographic status of children with type 1 diabetes.

\begin{tabular}{|l|c|c|c|c||}
\hline \multirow{2}{*}{ Variables } & \multicolumn{2}{|c||}{ Boys $(\mathbf{n = 2 0})$} & \multicolumn{2}{c||}{ Girls (n=20) } \\
\cline { 2 - 5 } & No & \% & No & $\%$ \\
\hline \hline History of Weight change & \multicolumn{5}{|c||}{} \\
\hline Weight gain & $\mathbf{6}$ & $\mathbf{3 0}$ & $\mathbf{7}$ & $\mathbf{3 5}$ \\
\hline Weight lost & $\mathbf{1 2}$ & $\mathbf{6 0}$ & $\mathbf{1 1}$ & $\mathbf{5 5}$ \\
\hline Weight not changed & $\mathbf{2}$ & $\mathbf{1 0}$ & $\mathbf{2}$ & $\mathbf{1 0}$ \\
\hline Exercise & \multicolumn{5}{|l}{} \\
\hline Yes & $\mathbf{1 1}$ & $\mathbf{5 5}$ & $\mathbf{5}$ & $\mathbf{2 5}$ \\
\hline No & $\mathbf{9}$ & $\mathbf{4 5}$ & $\mathbf{1 5}$ & $\mathbf{7 5}$ \\
\hline
\end{tabular}


Table (5): Hemoglobinlevel (g/d I) and blood glucose level $(\mathrm{mg} / 100 \mathrm{ml})$ for study samples.

\begin{tabular}{||l|c|c|c|c||}
\hline \multirow{2}{*}{ Parameters } & \multicolumn{2}{|c|}{ Boys } & \multicolumn{2}{c||}{ Girls } \\
\cline { 2 - 5 } & No & $\%$ & No & $\%$ \\
\hline \hline Hemoglobin Level & & & & \\
\hline Low <12 & 5 & 25 & 6 & 30 \\
\hline Moderate 13-14 & 12 & 60 & 10 & 50 \\
\hline High > 14 & 3 & 15 & 4 & 20 \\
\hline Blood Sugar & & & & \\
\hline Fasting & & & & \\
\hline$<70$ & 3 & 15 & 2 & 10 \\
\hline $70-130$ & 2 & 10 & 1 & 5 \\
\hline$>130:$ uncontrolled & 15 & 75 & 17 & 85 \\
\hline Post prandial & & & & \\
\hline$<160$ & 6 & 30 & 8 & 40 \\
\hline$>160:$ uncontrolled & 14 & 70 & 12 & 60 \\
\hline Random & & & & \\
\hline$<200$ & 7 & 35 & 9 & 45 \\
\hline$>200$ & 13 & 65 & 11 & 55 \\
\hline \hline
\end{tabular}

Table (6): The type of the meal snacks.

\begin{tabular}{|l|c|c|c|c||}
\hline \multirow{2}{*}{ Food } & \multicolumn{2}{|c|}{ Broups } & \multicolumn{2}{c|}{ Goys } \\
\cline { 2 - 5 } & No & $\%$ & No & $\%$ \\
\hline \hline Snack meal & & & & \\
\hline Yes & 17 & 85 & 18 & 90 \\
\hline No & 3 & 15 & 2 & 10 \\
\hline Chips & 8 & 40 & 4 & 20 \\
\hline Chocolate & 4 & 20 & 3 & 15 \\
\hline Ice Cream & 2 & 10 & 4 & 20 \\
\hline Sweets & 3 & 15 & 5 & 25 \\
\hline Jams & 3 & 15 & 4 & 20 \\
\hline
\end{tabular}


Table (7): Food behaviour for studies samples.

\begin{tabular}{|c|c|c|c|c|}
\hline \multirow[b]{2}{*}{ Variables } & \multicolumn{2}{|c|}{$\operatorname{Boys}(n=20)$} & \multicolumn{2}{|c|}{ Girls $(n=20)$} \\
\hline & No & $\%$ & No & $\%$ \\
\hline \multicolumn{5}{|l|}{ Number of meals daily } \\
\hline 3 & 5 & 25 & 3 & 15 \\
\hline 4 & 5 & 25 & 8 & 40 \\
\hline 5 & 10 & 50 & 9 & 45 \\
\hline \multicolumn{5}{|l|}{ Breakfast eating } \\
\hline Yes & 15 & 75 & 13 & 65 \\
\hline No & 5 & 25 & 7 & 35 \\
\hline \multicolumn{5}{|l|}{ Daily milk consumption } \\
\hline Yes & 11 & 55 & 12 & 60 \\
\hline No & 9 & 45 & 8 & 40 \\
\hline \multicolumn{5}{|l|}{ Frequency of daily milk consumption } \\
\hline 1 & 8 & 40 & 7 & 35 \\
\hline 2 & 3 & 15 & 5 & 25 \\
\hline \multicolumn{5}{|l|}{ Eating legumes } \\
\hline Yes & 6 & 30 & 8 & 40 \\
\hline No & 14 & 70 & 12 & 60 \\
\hline \multicolumn{5}{|l|}{ Eating egg } \\
\hline Yes & 16 & 80 & 14 & 70 \\
\hline No & 4 & 20 & 6 & 30 \\
\hline \multicolumn{5}{|l|}{ Eating red meat } \\
\hline Yes & 13 & 65 & 11 & 55 \\
\hline No & 7 & 35 & 9 & 45 \\
\hline \multicolumn{5}{|l|}{ Eating chicken meat } \\
\hline Yes & 20 & 100 & 19 & 95 \\
\hline No & 0 & 0 & 1 & 5 \\
\hline \multicolumn{5}{|l|}{ Eat fresh vegetables } \\
\hline Yes & 8 & 40 & 10 & 50 \\
\hline No & 12 & 60 & 10 & 50 \\
\hline \multicolumn{5}{|l|}{ Eat Fresh Fruit } \\
\hline Yes & 13 & 65 & 15 & 75 \\
\hline No & 7 & 35 & 5 & 25 \\
\hline \multicolumn{5}{|l|}{ Prefer bread } \\
\hline Bran & 4 & 20 & 7 & 35 \\
\hline White & 16 & 80 & 13 & 65 \\
\hline
\end{tabular}


Table (8): Mean \pm SD of macronutrients intake of children.

\begin{tabular}{|c|c|c|c|c|c|}
\hline \multirow{2}{*}{\begin{tabular}{|c} 
Groups \\
+Macro-Nutrients
\end{tabular}} & \multicolumn{2}{|l|}{ Boys } & \multicolumn{2}{|l|}{ Girls } & \multirow{2}{*}{ Sig } \\
\hline & Mean \pm SD & $\%$ of DRI & Mean \pm SD & $\%$ of DRI & \\
\hline Calories(K cal)\# & $2023.49 \pm 461.5$ & $101 \%$ & $1785.95 \pm 156.71$ & $90 \%$ & $* * *$ \\
\hline Protein -Animal (g) & $48.73 \pm 25.26$ & & $32.44 \pm 8.19$ & & $* * *$ \\
\hline Protein -Plant (g) & $19.76 \pm 10.56$ & & $23.58 \pm 7.17$ & & $* * *$ \\
\hline Total Protein(g) & $71.89 \pm 22.38$ & $256 \%$ & $53.44 \pm 3.4$ & $151 \%$ & $* * *$ \\
\hline Fat - Animal (g) & $60.31 \pm 33.71$ & & $38.20 \pm 9.53$ & & $* * *$ \\
\hline Fat - Plant (g) & $24.69 \pm 13.29$ & & $30.78 \pm 2.20$ & & $* * *$ \\
\hline Total Fat(g) & $85.0 \pm 27.32$ & & $68.10 \pm 4.75$ & & $* * *$ \\
\hline Carbohydrate (g) & $242.80 \pm 41.70$ & $87 \%$ & $241.67 \pm 47.61$ & $95 \%$ & $* * *$ \\
\hline Fiber $(\mathrm{g})$ & $6.48 \pm 4.74$ & & $4.03 \pm 0.61$ & & $*$ \\
\hline Cholesterol(mg) & $292.8 \pm 61.17$ & & $134.51 \pm 12.58$ & & Ns \\
\hline
\end{tabular}

\#RDA: Recommended Dietary Allowances(1989).

DRI: Dietary Reference Intake (2002). $\quad * \mathbf{p}<0.05 \quad * * * \mathbf{p}<0.001$

Table (9): Mean \pm SD of micronutrients intake of children.

\begin{tabular}{|c|c|c|c|c|}
\hline \multirow{2}{*}{\begin{tabular}{|r|} 
Groups \\
Micro-Nutrients
\end{tabular}} & \multicolumn{2}{|c|}{$\operatorname{Boys}(n=20)$} & \multicolumn{2}{|c|}{ Girls $(n=20)$} \\
\hline & Mean \pm SD & $\%$ of DRI & Mean \pm SD & $\%$ of DRI \\
\hline \multicolumn{5}{|c|}{ Minerals } \\
\hline Calcium (mg) & $1075.31 \pm 287.93$ & $134 \%$ & $622.96 \pm 105.85 * * *$ & $59 \%$ \\
\hline Phosphorus (mg) & $1152.77 \pm 174.06$ & $144 \%$ & $848.32 \pm 32.23 * * *$ & $83 \%$ \\
\hline Sodium (mg) & $1992.95 \pm 1486.5$ & $668 \%$ & $2196.89 \pm 198.7$ & $529 \%$ \\
\hline Potassium (mg) & $2120.12 \pm 588.96$ & $133 \%$ & $1874.09 \pm 173.17$ & $109 \%$ \\
\hline Magnesium (mg) & $298.23 \pm 78.21$ & $175 \%$ & $230.37 \pm 23.16 * * *$ & $126 \%$ \\
\hline Iron -A (mg) & $5.90 \pm 29.81$ & & $2.91 \pm 0.45$ & \\
\hline Iron -P (mg) & $6.37 \pm 4.14$ & & $5.36 \pm 0.90$ & \\
\hline Total Iron (mg) & $11.08 \pm 3.48$ & $110 \%$ & $7.73 \pm 0.53 * * *$ & $59 \%$ \\
\hline Zinc (mg) & $9.46 \pm 2.21$ & $95 \%$ & $7.14 \pm 1.66 * * *$ & $60 \%$ \\
\hline \multicolumn{5}{|c|}{ Vitamins } \\
\hline Vitamin-A $(\mu \mathrm{g})$ & $1087.46 \pm 348.88$ & $155 \%$ & $399.61 \pm 64.79 * * *$ & $\mathbf{5 8 \%}$ \\
\hline Vitamin-D $(\mu \mathrm{g})$ & $3.85 \pm 2.75$ & $39 \%$ & $2.65 \pm 1.26 * * *$ & $28 \%$ \\
\hline Vitamin-E (mg) & $11.09 \pm 5.70$ & $158.56 \%$ & $7.55 \pm 1.78 * * *$ & $95 \%$ \\
\hline Vitamin-C (mg) & $60.67 \pm 27.74$ & $134 \%$ & $96.91 \pm 60.64$ & $158 \%$ \\
\hline Vitamin-B 1 (mg) & $1.36 \pm 0.89$ & $135 \%$ & $0.79 \pm 4.03 * * *$ & $75 \%$ \\
\hline Vitamin- $B_{2}$ (mg) & $1.83 \pm 0.99$ & $152 \%$ & $0.74 \pm 8.74 * * *$ & $59 \%$ \\
\hline Niacin (mg) & $20.81 \pm 15.14$ & $160 \%$ & $16.06 \pm 0.81$ & $113 \%$ \\
\hline Vitamin-B $_{6}(\mathrm{mg})$ & $0.88 \pm 0.18$ & $63 \%$ & $1.05 \pm 0.24$ & $79 \%$ \\
\hline Vitamin-B $_{12}(\mathrm{mg})$ & $2.42 \pm 1.17$ & $173 \%$ & $0.60 \pm 0.34 * * *$ & $33 \%$ \\
\hline Flate $(\boldsymbol{\mu} \mathrm{g})$ & $256.58 \pm 48.19$ & $256 \%$ & $148.35 \pm 8.04$ & $125 \%$ \\
\hline
\end{tabular}

DRI: Dietary Reference Intake (2002). 


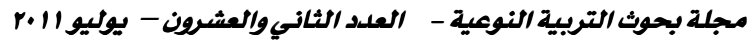

Table (10): Mean \pm SD of daily consumption (in g) of individual saturated and unsaturated fatty acids and their percentage of total FA for group according to different sex groups.

\begin{tabular}{|c|c|c|c|c|}
\hline \multirow{2}{*}{\begin{tabular}{|l} 
Groups \\
Fatty Acids
\end{tabular}} & \multicolumn{2}{|c|}{ Boys $(n=20)$} & \multicolumn{2}{|c|}{ Girls $(n=20)$} \\
\hline & Mean \pm SD & \% T.sat & Mean \pm SD & \% T.sat \\
\hline \multicolumn{5}{|l|}{$\begin{array}{|ll|}\begin{array}{l}\text { Saturated } \\
\text { acids }\end{array} & \text { fatty } \\
\end{array}$} \\
\hline $\mathrm{C}_{10: 0}$ & $11.28 \pm 0.64$ & $18.70 \%$ & $9.66 \pm 0.45$ & $25.29 \%$ \\
\hline $\mathbf{C}_{12: 0}$ & $10.42 \pm 0.21$ & $\mathbf{1 7 . 2 8 \%}$ & $4.26 \pm 0.25$ & $11.15 \%$ \\
\hline $\mathrm{C}_{12: 0}$ & $12.36 \pm 1.34$ & $20.49 \%$ & $5.67 \pm 1.19$ & $14.84 \%$ \\
\hline $\mathbf{C}_{16: 0}$ & $10.63 \pm 0.37$ & $17.63 \%$ & $6.26 \pm 0.13$ & $16.39 \%$ \\
\hline $\mathrm{C}_{18: 0}$ & $13.13 \pm 1.46$ & $21.77 \%$ & $7.42 \pm 0.69$ & $19.42 \%$ \\
\hline $\mathbf{C}_{24: 0}$ & $2.49 \pm 0.35$ & $4.13 \%$ & $4.93 \pm 0.17$ & $12.91 \%$ \\
\hline Total & $60.31 \pm 3.13$ & $100 \%$ & $38.20 \pm 2.01$ & $100 \%$ \\
\hline $\begin{array}{l}\text { Monounsaturated } \\
\text { fatty acids }\end{array}$ & & $\%$ of T. Mono & & $\%$ of T. Mono \\
\hline C16:1 & $10.34 \pm 4.75$ & $50.84 \%$ & $8.19 \pm 4.29$ & $35.58 \%$ \\
\hline C18:1 & $7.43 \pm 3.21$ & $36.53 \%$ & $7.59 \pm 0.46$ & $32.97 \%$ \\
\hline C20:1 & $0.33 \pm 0.35$ & $1.62 \%$ & $4.24 \pm 1.34$ & $18.42 \%$ \\
\hline C22:1 & $2.24 \pm 1.23$ & $11.01 \%$ & $3.00 \pm 0.10$ & $13.03 \%$ \\
\hline Total & $20.34 \pm 4.20$ & $100 \%$ & $23.02 \pm 4.30$ & $100 \%$ \\
\hline $\begin{array}{l}\text { Polyunsaturated } \\
\text { fatty acids }\end{array}$ & & $\%$ of T. Poly & & $\%$ of T. Poly \\
\hline C18:2 & $3.03 \pm 3.34$ & $69.66 \%$ & $5.73 \pm 1.35$ & $83.28 \%$ \\
\hline C18:3 & $1.32 \pm 0.18$ & $30.34 \%$ & $1.15 \pm 0.83$ & $16.72 \%$ \\
\hline C20:4 & $000 \pm 000$ & $\mathbf{0 . 0 \%}$ & $0.00 \pm 0.00$ & $\mathbf{0 . 0 \%}$ \\
\hline Total & $4.35 \pm 2.33$ & $100 \%$ & $6.88 \pm 2.64$ & $100 \%$ \\
\hline
\end{tabular}

Table (11): Mean \pm SD of fatty acids (g) and percentage of essential FA intake of (RNI) according todifferent sex groups.

\begin{tabular}{|c|c|c|c|c|}
\hline \multirow{2}{*}{ Fatty Acids } & \multicolumn{2}{|c|}{ Boys $(n=20)$} & \multicolumn{2}{|c|}{ Girls $(n=20)$} \\
\hline & Mean \pm SD & D.I & Mean \pm SD & D.I \\
\hline Omega-6 FA (RNI=11.43) & $3.03 \pm 3.34$ & $26.58 \%$ & $5.73 \pm 1.35$ & $\overline{50.26 \%}$ \\
\hline Omega-3 FA (RNI=1.9) & $1.32 \pm 0.18$ & $69.47 \%$ & $1.15 \pm 0.83$ & $60.53 \%$ \\
\hline T.unsat FA/T.sat. & \multicolumn{2}{|c|}{0.41} & \multicolumn{2}{|c|}{0.78} \\
\hline $\mathbf{P} / \mathrm{S}$ & \multicolumn{2}{|c|}{0.072} & \multicolumn{2}{|c|}{0.180} \\
\hline
\end{tabular}

P/S: T. Ployunsat. FA/T. sat . FA.

DI: Dietary Intake RNI: Recommended Nutrient Intake 


\section{References}

1. American Diabetes Association (2000): Nutrition Recommendation and Principles for People With Diabetes Mellitus. Diabetes Care. 23 Suppl 1s43-6.

2. American Diabetes Association (2001): Clinical Practice Recommendations. Diabetes Care, 24 (Suppl) 1:S1-133.

3. DRI (2002): Dietary Reference Intake for Energy, Carbohydrate, Fiber, Fat, Fatty Acid, Cholesterol, Protein and Amino Acids. Institute to Medicine, T.O.M. This Report May Be Accessed Via www.nap.edu.

4. Habib Hs(2005): Frequency and clinical characteristic of ketoacidosis at onset of childhood type 1 diabetes mellitus in Northwest Saudi Arabia . Saudi Med .J, 26(12):1936-9.

5. Jasinski, D; Pilecki O; Robak-Kontna, $\mathrm{K}$ and Zbikowska-Bojko M(2003): Analysis Of Type 1 Diabetes Mellitus Symptoms at Admission to Hospital. Endokrynol. Diabetol. Chor. Prezemiany. Materii. Wieku. Rozw, 9(2):83-7.

6. Jelliffe, D B (1966): The Assessment Of Nutritional Status Of Community, World Health Organization,Geneva,74-76.

7. Krauss, M.V. and Mohan, H .K.(1992): Food Nutrition Diet Therapy. SW .B. Saunders, Philadelphia.

8. Kylberg,E: ; Ewald U; Tuvemot and Gebre. Medhin, M.(1985): Dietry Intake in Swedish Diabetic Children. Acta Paediatr. Scand Suppl., 320-32 (7).

9. Larsson, HE; lynch K; Lernmark B; Hansson G; Lernmark A; and Ivarsson SA (2007): Relationship Between Increased Relative Birthweight and Infections During Pregnancy In Children With a High-Risk Diabetes HLA Genotype. Diabetologia. Apr 40.

10. Nafiu, O. O, Reynolds PI, Bamgbade, O.A; Tremper, K.K; Welch, K and Kasa - Vubu, J.z(2007): Childhood body mass index and perioperative complications. Pediatric Anaesth., 17 (5):426-30.

11. Nutrition Institute (1996): Food Composition Tables, Row, Processed, Prepared.

12. Orton, H.D; Szabo, N.J; Clare-Salzler, M. and Norris, J.M .(2007): Comparison Between omega-3 and omega-6 polyunsaturated fatty acid intakes as assessed by a food frequency questionnaire and erythrocyte membrane fatty acid composition in young children . Apr 180.

13. Patton, S.R; Dolan, L.M and Powers, S.W.(2007): Dietary adherence and associated glycemic control in families of young children with type 1diabetes. J. Am. Diet. Assoc., 107(1):46-52.

14. RDA(1989):Recommended Dietary Allowances, $10^{\text {th }}$ Edition, National Academy of Sciences Press, Washington. 
15. Rosenbauer J; Icks A and Giani G(2002): Clinical characteristics and predictors of severe ketoacidosis at onset of $\mathrm{T}$ ype 1 diabetes mellitus in children in a North Rhine Westphalia Region. Jpediatar. Endocrinol. Metab., 15(8): 1137-45.

16. SPSS (1998): Statistical Package for Social Social Science, Computer Software, Ver.10.SPSS.Company. London.UK.

17. Waterman, C.S.; Atkinos, E.E .; Wilkins ,B. ; Fisher, C.L. and Kimsey ,S.L.(1975): Improve measurement of erythrocyte volume distribution by aperture-countersignal analysis, Clin Chem.,21:1201-1211.

18. WHO (1995) Physical status:The use and interpretation of anthropometry Report of a WHO Expert Committee.Geneva,World Health Organization, (Technical Report series No.854);368-369. 
z to za gearn: Cirli

Ablut Pediatrics

Worts muss hudlex-for-oge pencentiles

Mises:

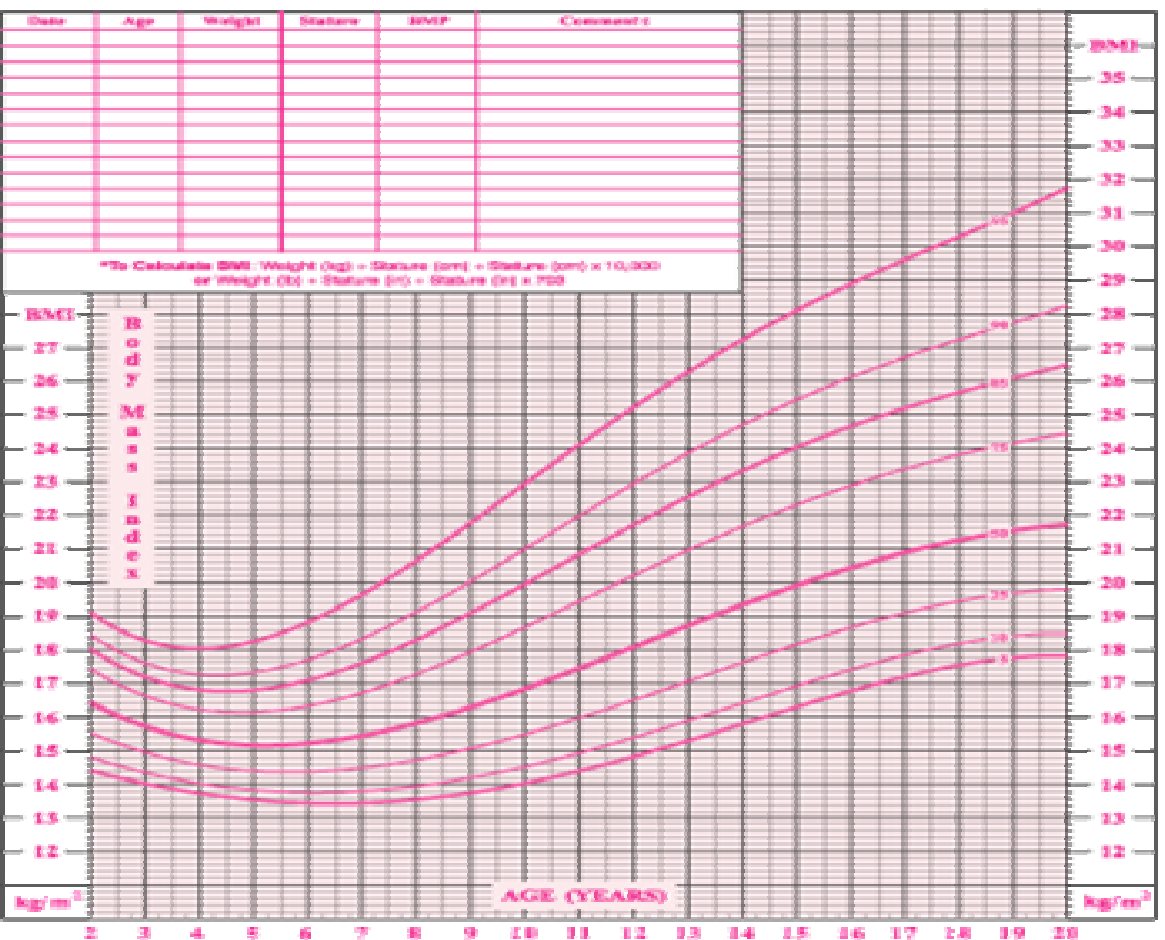

SOURCE: Developed by the National Center For Health Statistics in Collaboration With the National Center for Chronic Disease prevention and Health promotion (2000). 


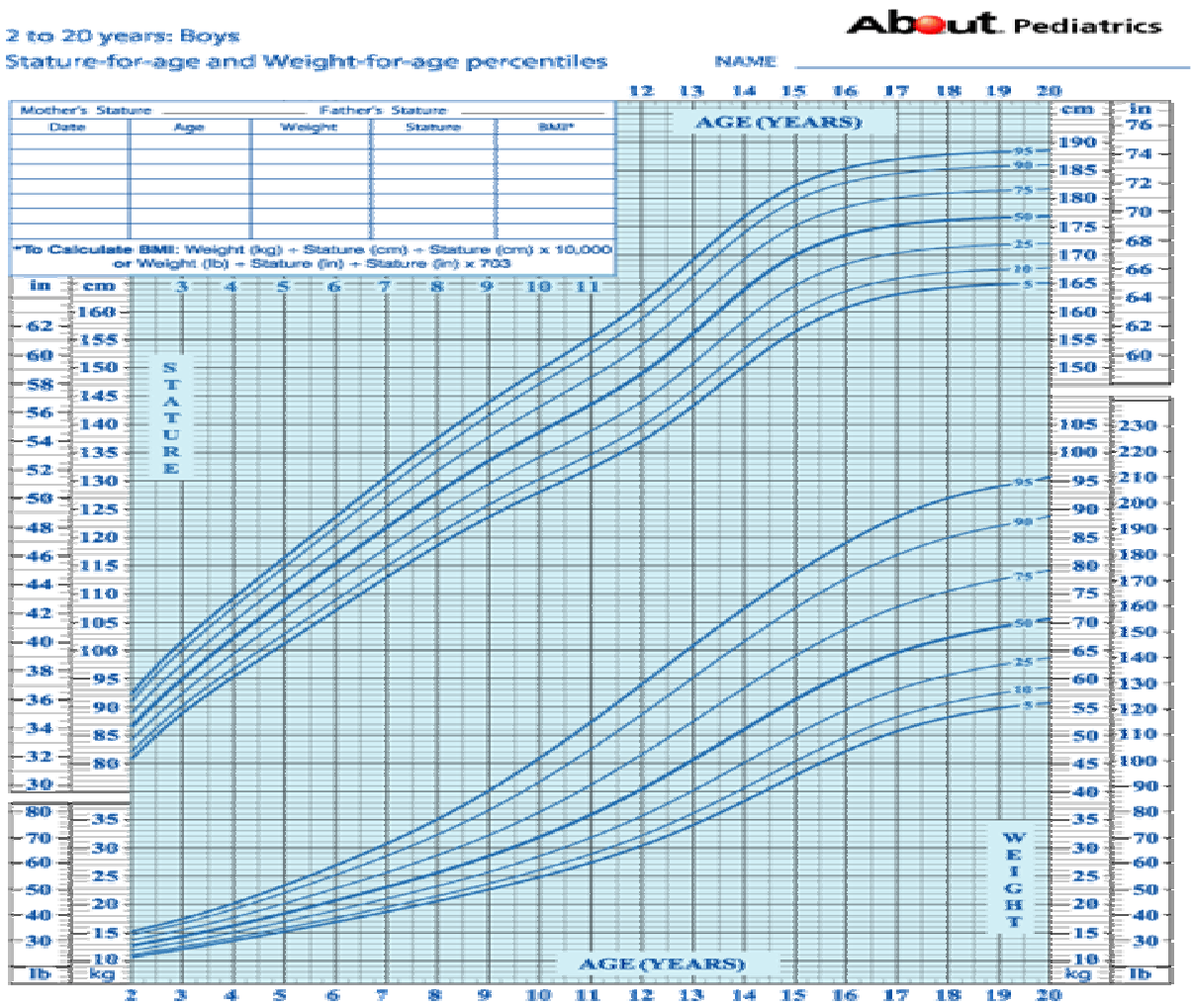

SOURCE: Developed by the National Center For Health Statistics in Collaboration With the National Center for Chronic Disease prevention and Health promotion (2000). 


\title{
تقييم الحالة الغذائية والصحية عند الأطفال المصابين بالداء السكرى
}

\author{
د/ منى ابراهيم محمد نجا \\ قسم الاقتصاد المنزلى _ كلية التربية النوعية _ جامعة المنوفية
}

تلعب التغذية دورا مههم يِّ التحكم مِّ الوزن ومعالجة السمنـة والسكري عند الأطفال

هِ سن المدرسلة. وتهدف هذه الدراسـة إلي تقييهم الحالة الغذائية والمقاييس الجسمية والنظام

الغذائي لعينة من النوع الأول والذين تم اختيارهم من معهد السكروبلغ عددهم ( •ع ) ) مريض تتراوح أعمارهم بين - - rا سنة . حيث تم تقدير المتناول من الغذاء والمقاييس الجسمية وبعض التحاليل المعملية التي شملت نسبة الهيموجلوبين ومستوي السكر ِِّ الدم ـوقد أشارت النتائج أن متوسط الوزن والطول كان مـرتفعا عند الإناث .وان غزارة البول والعطش الشديد من أكثر الأعراض الذي يعاني منه الجنسين من الأطفال. والمتناول من العناصر الغذائية أعلي من الاحتياجات بالنسبة للجنسين ماعدا السعرات والكالسيوم و الفوسفور والحديد والزنك وفيتامين أ B مان أقل من الاحتياجات عند الإناث . بينما وجد

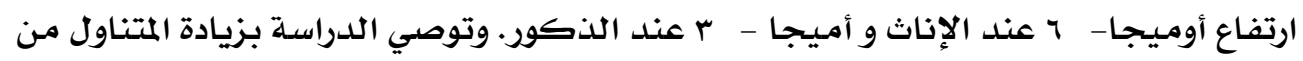

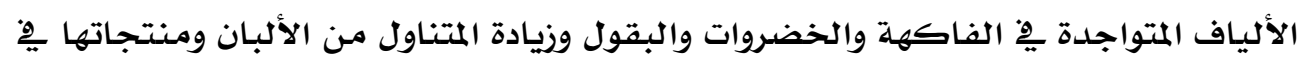
الوجبة والإقلال من تناول الوجبات الخفيفة والسريعة وزيادة الوعي الغذائي والصحي كلأطفال وأمهاتهم. 